\title{
The Method of Recognizing International Law
}

\author{
Alireza Azadikalkoshki*, Mohsen Hosseinabadi \\ FEBIT International Law Office, Istanbul, Turkey \\ Email: *f.o.20@febitmail.com
}

How to cite this paper: Azadikalkoshki, A., \& Hosseinabadi, M. (2018). The Method of Recognizing International Law. Open Journal of Political Science, 8 , 152-162.

https://doi.org/10.4236/ojps.2018.82012

Received: November 15, 2017

Accepted: April 10, 2018

Published: April 13, 2018

Copyright @ 2018 by authors and Scientific Research Publishing Inc. This work is licensed under the Creative Commons Attribution International License (CC BY 4.0).

http://creativecommons.org/licenses/by/4.0/ (c) (i) Open Access

\begin{abstract}
The United Nations, as the central core, coordinates the steps taken to establish international peace and security and to develop friendly relations between countries, based on the principle of equality of rights and autonomy of nations, and achieve international cooperation in the sphere of economic, social and cultural affairs and encourage governments to respect human rights and fundamental freedoms. Hence, all countries should, with respect to membership in the organization, act in accordance with the obligations under the Charter and resolve all their international disputes through peaceful means, based on the principles of justice and international law. However, there are two methods for recognizing international law: the method of social cognition and rational method. The social recognition method of the international system is to abandon theoretical insights of international law and address existing facts and to extract the patient and accurate historical and social data that constitute the living material or the substance of the legal rule. The method of the logical recognition of the principles and rules of international law is to explain the nature and method of legal argument that has a significant impact on the proper understanding of the legal rules and the recognition and analysis of international law and finally the introduction of a system governing international relations. Using the first method, the international community is described first. Then, its life is studied in motion (inductive method); as using the second method, the accuracy and inaccuracy of those cases and judgments are evaluated, which are the introduction of other judgments (deductive method). These two methods, that is, the objective observation of events and logical reasoning, if coordinated, will pave the way for the analysis of the international system and explain its characteristics, and international law will be in its place.
\end{abstract}

\section{Keywords}

International Law, Rational Method, Social Recognition Method 


\section{Introduction}

The international community is fundamentally different from the national community; therefore, the rules governing the international community do not have the integrity and coherence of the internal system. In the international community, as in any other society, there are relations that are the result of various social actions. According to Max Weber, "any human behavior is a kind of internal or external state that is intended to perform or refrain from doing an action. Of course, this behavior is considered an action, for which human beings have defined a certain meaning. If this action is combined with the actions of other individuals, creates social action that has significant impact on the growth and development of it. Social action is the first stage of social relations, because in the realm of everyday life of man, essentially, every action is influenced by another, and from all of them, social relations emerge." International relations, to a much wider extent, are the result of social interaction. Now, if we isolate international relations from other social relations in order to get the concept of the "international community", we find that such actions have exceeded not only the national boundaries, in the specific sense of the word, but also the borders of a state intertwined with the actions of other nations. In the community of states, the actions of each state are influenced by the actions of the other state or stated, to the extent that, from all these actions, an order has emerged, which has taken the form of a rule through repetition and continuity, and or because of complementary factors, has been legitimized in the form of international treaties. The relationship that governments have established with each other, and individuals and groups under their sovereignty have given it a specific concept, has been a way to move the relationships of individuals within the international community. Therefore, it cannot be imagined that governments would destroy that path that has been plagued with great difficulty and, consequently, eliminate the order created in this way, and generally called international law. Nevertheless, governments continue to be subject to immediate international law, which means that they are rules that govern the entire human society. This situation actually reflects the present nature of international relations, in which only governments are able to make decisions. Obviously, if the structure of this society is torn down and the power belongs to those individuals and groups, a unified, organized society will emerge, in which the law will govern all members equally. Hence, the rational recognition of the rules and regulations, that governments have created and imposed on the international community within the boundaries of these organizations or on their own will, is possible only by properly understanding the techniques and methods of particular international law, that is, rules and regulations deriving from the will of governments, because, in fact, the same rules and regulations are the basis of legal arguments in relations between governments (Falsafi, 2006: p. 2). If the purpose of the investigation is merely to deal with purely legal issues or the legal institutional basis, this method alone is sufficient, but if it is to seek a basis for rules and regulations, its inadequacy will 
be apparent because the basis of the law is the facts that are outside its structure and can be understood only through the sociological method, that is, through objective observation. International law, like any other legal system, is a domain whose knowledge requires the use of both logical and sociological methods because in the construction of this system there are many influential non-legal actors who, along with any legal argument, should consider them Consider. Given that the details of these two methods are beyond the scope of the research, we will pass the rational method in this article and discuss in detail the topic of social recognition of international law.

\section{Pure Legal Cases and Legal Methodological Cases}

In order to address the subject, one should pay attention to this important entry that legal cases are divided into two categories: 1) pure legal cases; 2) legal methodological cases.

The pure legal cases are the cases that generally determine how human behavior is in the domain of certain material things, but the legal methodological cases are cases that are general, to the extent that they can be used to implement any legal rule, regardless of the content that it contains. In international law, pure legal cases are the cases in which an international arbitrator or judge can directly invoke them, using the techniques and procedures related to the implementation of international law, and thus issue a ruling on that basis. In such cases, the judge's argument is based on cases that have existed before (before the occurrence of dispute). Of course, it is possible that the same cases are the cause of the acquisition or implementation of another case, which has been obtained, for example, through an allegorical argument and can be used to solve other problems in that domain. For example, paragraph 8 of article 19 of the Constitution of the International Labor Organization (Lapidoth, 1987: p. 143) stipulates that "in no case, the adoption of a convention or recommendation at a conference or ratification of a convention in countries should not result in this that the member state would limit the support that the domestic legislator had already made to the workers." This, in fact, has established a basis for interpreting the recommendations or conventions of international labor conferences, which are only applicable in the same area. In other words, paragraph 8 of article 19 of the Constitution of the International Labor Organization merely refers to a certain category of rules and regulations relating to the protection of workers' rights that the International Labor Conference has been involved with. Therefore, this is a case law, and does not involve any methodological principle, since the case concerning the proper implementation of the rules of law is the main implication of a methodological approach whose content is general and can be used to enforce any legal rule. For example, if it is said that "every treaty must be interpreted in good faith" (Article 31 of the 1969 Vienna Convention), it is said from a methodological principle that its realm is not limited to a specific treaty.

"It's not so easy to distinguish legal rules from methodological principles, 
and it does not have a lot of practical value, but it's very important because it describes the extent of studies on the methodology of law" (Singh, 1970: p. 315).

\section{Legal Cases and Their Logical Structure}

\section{The Logical Form of the Cases}

In each organized society, the domestic legislator has established general rules for creating peace and social security so that people can solve their daily problems by referring to them. Of course, given the lack of uniformity in the nature of social problems and issues, one might argue how one can solve a variety of social problems using a general rule. The answer is that, in such cases, since social stability and social security are of priority to the provision of justice in the specific sense of the word, the legislator has given the society a political unity with a partial solution of the cases, so that, as a result of the stability of the rules, legal security prevail in that society. For this reason, the legislator, by neglecting thousands of objective events, has established fixed rules that help resolve many issues (Maniruzzaman, 1993: p. 229). These rules, by drawing the general framework, accurately have determined the main elements of each situation, so that in each framework the criteria of objective facts have been determined. However, changes must be made in order for each event to fall within its legal framework. Of course, not to the extent that the reality is transformed, because the correct law is the law that incorporates objective cases with only a slight change in its form, which itself requires that, in any legal case, the concepts contained in it be, in general, of objective events. In international law, the legal situations arising from the custom or basic conventions are also universal, which means that the international general rules, in principle, without regard to the parties to the treaties, take into account the type of relationship, and have created consistent rules for them. Of course, it's also worth noting that in the international community, legal regulations have been created through the coordination of the will of governments, that is, those who have worked together to balance their interests in the realm of various affairs.

\section{Legal Argument}

The purpose of any legal argument is to find a solution to problems that generally affect individuals or governments, so the logic decides that the solution is sound and comprehensive. Obviously, the basis of each argument is found in a legal rule that may have a very limited scope and has made its legal effects conditional on the realization of certain circumstances. However, the rule of law must, in all cases, have a broader scope than the legal issue which is the basis of the argument, since justice and logic require that the legal rule equally governs all members of the community, and this requires that the verdict of each rule in similar cases be considered in the same way for all (Singh, 1970: p. 320). For this reason, they have used abstract concepts for legal regulation, which involves ab- 
stract characteristics and various social situations. These concepts are divided into many categories in every realm, as far as in each discipline of international law regular classes of abstract concepts have emerged. For example, International Maritime Law, which is a set of rules and regulations governing the activities of governments in the sea, is a category of public international law and concepts contained in the provisions of the internal waters, the territorial sea, the adjacent region, the Free Sea, the exclusive economic zone. Each is a specific category of international maritime law. Each of these general rules, or more precisely, every major case, is in the international law of two components: 1) the hypothesis of law; 2) the result or the sentence. These two components are in-depth and expansive in detail, which does not fall within the scope of this article and require a thorough and detailed study of this subject. The international judge is obligated, using reasons and examples, to reconstruct the event appropriately, so that it can adapt the objective event to the legal standard. This very well shows that the legal argument differs from pure logical reasoning. It seems that the acknowledgment of the legal nature of objective events has not always been a matter of logical rules, and it has often happened that such an acknowledgment has been influenced by the values prevailing over the international community or the interests and benefits of governments that have benefited or lost from the enforcement of a legal rule. In the following, we examine the social recognition method by considering the basic components and parameters of this method in international law.

\section{The Sociological Study of Methods of Recognition of International Law}

The sociological approach is the only way to realize the depth of international realities and to eliminate the shortcomings of traditional international law. This method, while apparently contradicting the logical method of knowing the rules, actually, complements it and removes dusts from its face. In other words, these two methods, while having a different view of the other, have a single subject linking them together, which means that "if dogmatic law searches an issue from within, its sociology looks it from the outside." Thus, it is only by studying the sociology of international law that it can be seen why international law has only regulated a part of international relations and is unable to resolve issues in which there are many political contradictions. Therefore, addressing the international realities creates a link between what "is" and what "should be", or at least attenuates the conflict between these two concepts. As a result, it can be said that the goal of the sociological study of international law is not to negate the law and its existential philosophy, but to expand the views that have a significant impact on the development and evolvement of this system (Falsafi, 2007: pp. 50-49). In the sociological study of the rules and regulations of each system, rights are not only studied as closed realms, but are viewed as part of reality. Due to such studies, the impact of law on social reality and the influence of social reality (that is, what 
is outside the realm of law and is effective in the creation and survival of the wisdom of the legal rule) on law is revealed. Therefore, getting the weaknesses or strengths and the extent of the growth and development of any legal system is possible when we consider it to be part of social life, because "in fact, social life does not come to order just by law, but other factors, such as customs and ethical, religious, school, political, economic beliefs and even the geographic location of countries, population density, military strength, ethnic strategic opportunities are also involved in making this order." (Morgenthau, 1940: p. 237). In other words, each legal rule belongs to a certain environment and originates from forces that are in the space belonging to it. These forces, which form the "material" of the legal rule, if they coordinate with the "face" of the rule, create an appropriate situation for society that represents the growth and development of the importance of that society, and therefore the effect of each rule in each environment is different; The rule that is useful in an environment may be harmful in other environment. Like all other legal systems, international law is also a domain whose knowledge requires the use of both logical and sociological methods, because, in the construction of this system, there have been many influential non-legal factors that, along with any legal argument, should be considered. According to one of the experts, the discussion of the main theme of international law is only part of the analysis. In order for research to be organized, international beliefs, the conduct of countries and international ethics must also be evaluated in order to create a complete picture of international law (Schmitt, 2011: pp. 2-8). Hence, the interest in the appearance of rights and the forgetting of its substance in international relations, in which specific rules prevail over general rules, weakens the foundations of any legal argument and rules the dogmas of the abstract logic of relations between the countries. For this reason, for the sake of understanding the international system, it is not enough to examine only the rules of reason and rules and the hierarchy between them; Because these rules have content that is shaped in view of the deep ethnic and historical differences of nations and the inequality of countries in enjoying the resources of wealth and being organized or unorganized of their interactions and the new requirements of the international organization (Falsafi, 2007: pp. 50-45). The sociological study of international law requires research into the relation between international law and social reality and how it evolves. Therefore, we have divided this discussion, in terms of methodological principles, into two parts: In the first part, we have examined the relationship of international law with those realities that, by themselves, were imposed on the community of nations and had no basis other than their political community. In the second part, we have considered the life of international law in motion, thereby identifying the factors of change and the causes of its instability.

\subsection{Conditions and the Order of the International Law}

The main task of the law is to organize the society, that is, to restrain the instinct 
of selfishness and violence, to provide social life and to coordinate the material and spiritual activities of members of society, and its basis is the modes of action, thought and emotion, which are outside the people (Durkheim, 1976: pp. 36-24) and made them obedient (ibid., 25). Law is always far from its foundation. This distance, depending on the social situation, is sometimes high and sometimes is in place and harmonious. The far distance indicates the imbalance of the rule, that is, the rule resistance to the appearance, and the harmonious distance is the sign of rule steadiness, that is, the rule alignment with appearance. This gap in the autocratic systems is high and in the free world is low. For this reason, in autocratic systems for enforcing legal regulations, the government is violent and in its free regime, the compulsion and the obligation to observe the legal rule it appears with mildness. In the first type, there is no guarantee of the implementation of a legal rule because the form of the rule does not follow its basis and the law is passed on in credit of individuals, which means that certain situations overcome general situations. But in systems of the second type, the guarantee of the implementation of a legal rule is universal and the same, because the law is created in credit of relation type the type of relationship and, as a result, the general situations prevail over the particular situations. "In such systems, the legal rule continues until that social data maintains its original value" (Weil, 1983: p. 165). But in the international system, the appearance of rule has not always complied with its foundation, and as a result, there has not been balance between the obligation to observe the rules of freedom of the members of the community; As we see in the contractual international law, in which the agreement of the will of the countries has been considered the formal source of the rules and regulations, such an agreement, sociologically, sometimes has been the result of overcoming one's will over another, and sometimes the result of real harmony of the will of the parties. International law is, in the first sense, the same classical system imposed by pressure and force on other countries (European international law in the nineteenth and early twentieth centuries), and today its foundations remain valid. International law in the second sense is the same set of rules and regulations that has emerged in the international community since 1946, taking into account the facts of social life, and has taken over part of international relations.

\subsection{International Classics Law}

The classical international system, which, like autocratic systems, is a fragmented system, has never created a necessary balance between the freedom of the members of the international community and the requirement arising from reality and this has meant that the international community had members that were different from each other in terms of racial and historical backgrounds and inequality in the availability of economic resources and the degree of social interactions (Koskenniemi, 2003: p. 40). In this heterogeneous society, individual interests have consistently dominated collective interests, and social regulations 
have not been universally acknowledged (Falsafi, 2007: p. 64). Furthermore, a requirement that was in the classical international law provisions has not been identical to the domestic regulations and has been different from it; because, the obligation to observe domestic regulations is universal, while the international obligation has always had a personal aspect and placed a country in a state of another (Morgenthau, 1940: p. 242). In other words, in internal systems, if people violate a legal rule, their society, itself, does not do anything, but the government, as the supreme institution, immediately responds to and punish perpetrators the law. And as a result, it dominates the social conditions. But in classical international law, the international enforcement system has never been widespread and universal and one or more governments has consistently stood against the trespassing government or governments and called for the implementation of a legal rule. The system of collective defense, which is predicted to punish countries violating international rules in the charter system, is also based on such an insight. Therefore, in the international community, in spite of the expansion of transnational actions, only governments can enforce international law. As a result, these governments, as much as they are the establishers and guarantors of the implementation of the legal rule, can violate, threaten, and eventually eliminate it (Falsafi, 2007: p. 65). Hence, it can be concluded that in the international community, which has a classical structure, only governments can respond to violations of international law (Norton, 1991: p. 209). Nevertheless, their reaction is, to a certain extent, acceptable that the implementation of the rule essentially entails a legal benefit for them, which means that the government alleging a breach of the law does not only have to prove that the other government has committed a crime and, as a result, has violated international law, but it must also argue that violating such a rule essentially has damaged the privileges it has earned from this rule (Falsafi, 2007: p. 66). The rules of classical international law, not only as domestic law have not been universal, but have not had much stability. Experience has shown that the internal system of each country, during hard riots, has lost its stability and continuity. In such a situation, the domestic legislator, by introducing successive laws and taking into account specific situations, has abandoned the principles of the law and has undermined the stability and continuity of the legal system (Morgenthau, 1940: p. 166). This instability, which in the internal systems is exceptional, has always appeared in the classical international system, and that's because the international community has always been the scene of the country's struggle and campaign due to international continuing disputes. These differences, which today have found more acute reasons and causes, have eliminated the balance of the international society and the stability of the international system and they have prevented that in one case, the repeated behavior of countries will be the basis of a stable custom. In the international system, unlike internal systems that have acquired the law of legitimacy from a constitutional and principled form, international rules derive their legitimacy from the principles that have emerged in terms of social reali- 
ties.

\section{Contemporary International Law}

So far, we have spoken of the rules and regulations imposed on the countries of the world in terms of historical determinism. Now, we need to go to the rules and regulations that have a real basis and have been revealed by the free will of the international law followers in certain formats called the custom and the basic treaty. In this sense, the custom and treaty have both the same nature, because each one represents the inherent right or the social system that existed before the conclusion of the treaty or the formation of the custom. Therefore, the validity and legal value of such rules and regulations are not based on the will of the countries; however, they will in practice invoke it and make it the basis of their legal actions. On the one hand, these rules and regulations are the result of the material solidarity of the members of the international community, which, along with massive social changes, have come to one another to meet their everyday needs, and on the other hand, it comes from spiritual solidarity, whose fiber have gradually been woven in the contemporary international community, and has created familiarity and affection, albeit modestly, between them (Falsafi, 2007: p. 71). The custom and general treaties are identical in terms of the effect they create themselves, and they are not the same. Because, both determine a form of qualifications and regulate abstract legal situations. Hence, the custom and treaty, in a way, reflect the common interests of the countries. Obviously, if these benefits are clear, the content of international law is also clearer and less likely to be denied. Common interests are the cause of concluding collective treaties and a genuine basis for international law; because all countries agree on its maintenance, and, in principle, no country alone can protect it. For this reason, the implementation of such treaties does not, in principle, create a problem because it does not alter the interrelationship between countries and the basis of their authority and does not affect their vital interests. The obligations that countries in the Charter, the Treaties on the Rights of the Sea, the Consular and Diplomatic Treaties, the Treaty Treaties (1969), the Statute of the International Court of Justice, and in particular the Declarations on the International Criminal Court's jurisdiction (paragraph 2 of article 36) have accepted, all of them represent the interests and, consequently, the authority of law in international relations and the obedience of neutral authorities to resolve international disputes and crises, to the extent that countries that have not joined these treaties have psychologically made themselves bound to observe the rules; Because these rules and regulations have become a universal custom for them. Of course, it should not be forgotten that the conclusion of these treaties has always been based on several sociological conditions, such as the relaxation of the political climate in the international community and the spiritual solidarity between countries within the scope of these treaties (Norton, 1991: p. 249). The analysis of the content of such treaties clearly shows that law is not far from its foundation and is in harmony with social reality, because the freedom of the parties is 
not limited to violence, although it has sometimes happened that the parties to the basic treaty have differed in their interpretation of a rule; However, such a controversy has not meant that resistance and resistance, which the followers of the law have shown themselves in relation to the classical imposed rules. In such cases, the law is, to a certain extent, affiliated with its foundation, which accepts every social change and immediately adapts itself to it; Because, as Bismarck believed, "international politics (and international law) is like a liquid that is sometimes thickened, depending on the situation and the atmosphere, but if the political climate changes, it will turn into its initial state and become diluted" (Ibid, 256). As a result, it can be said that the legal situation arising from the custom or conventions has three characteristics: first, that it has the whole, and, moreover, it has a continuity, and finally, it is binding (Falsafi, 2007: p. 74).

\section{Conclusion}

As we have seen in this study, the methods of recognizing international law require the use of both logical and sociological methods; that is, in spite of the use of legal reasoning, one has to pay attention to non-legal factors along with any legal argument. If we want to deal with purely legal issues, the rational method alone is sufficient, but if the goal is to seek the basis of rules and regulations, its inefficiency will be revealed; because the basis of law is the facts that are located outside its structure and can be understood only by the sociological method, that is, by objective observation. The methods of recognizing international law were characterized by the division of pure legal cases and legal methodological cases. Pure legal cases are cases which are generally defined as human behavior in the realm of certain material matters, but the methodological cases are legal cases that are general, to the extent that they can be used to enforce any legal rule, regardless of the content that it has. The division, indicates the two sociological and logical methods in the recognition of international law in a clear way. In a rational method, the international referee or judge, using the techniques and methods related to the enforcement of international regulations, directly refers to them and, therefore, issues a ruling on that basis. In such cases, the judge's argument is based on cases that have existed before (before the dispute). Here, the legislator, with the abandonment of thousands of objective events, lays down fixed rules that help resolve many issues. These rules, by drawing the general framework, accurately have determined the main elements of each situation, so that in each framework the criteria of objective facts have been determined.

In order to draw up a rational method for recognizing international law, abstract concepts have been used to lay down legal rules that entail abstract features and various social situations. These concepts are divided into many categories in each realm, to the extent that, in each of the disciplines of international law, regular classes of abstract concepts have emerged. For example, the concepts contained in the rules on the rights of seas, forests, mines, monopoly-economic areas, etc. are each a particular category of international law. In 
contrast to this methodology, the sociological approach is a method by which one can realize the depth of international realities. This method, while apparently contradicting the logical method of knowing the rules, actually, complements it and removes dusts from its face. Thus, addressing the international realities creates a link between what is "is" and what it should be and reduces the conflict between these two concepts. As a result, it can be said that the goal of the sociological study of international law is not to negate the law and its existential philosophy, but to expand the views that have a significant impact on the development and evolvement of this system. In the end, it should be noted that each legal rule belongs to a certain environment and originates from forces that are in the space belonging to it. These forces, which form the substance of the legal rule, if matching the rule, create a suitable situation for society, which represents the growth and development and the importance of that society.

\section{References}

Durkheim, E. (1976). The Rules of Sociology Method. A. M. Kardan, Trans. Tehran: Tehran University Press.

Falsafi, H. A. (2006). International Law Recognition Methods. Tehran: Institute for Humanities and Cultural Studies.

Falsafi, H. A. (2007). Methods of Recognizing International Law (Logical Recognition of International Law). Tehran: Research Institute for Humanities and Cultural Studies.

Koskenniemi, M. (2003). What Is International Law for? International Law, 3, 32-57.

Lapidoth, R. (1987). Equity in International Law. Israel Law Review, 22, 161-183.

Maniruzzaman, A. F. (1993). Conflict of Laws Issues in International Arbitration: Practice and Trends. Arbitration International, 9, 371-404. https://doi.org/10.1093/arbitration/9.4.371

Morgenthau, H. J. (1940). Positivism, Functionalism, and International Law. American Journal of International Law, 34, 260-284. https://doi.org/10.2307/2192998

Norton, P. M. (1991). A Law of the Future or a Law of the Past? Modern Tribunals and the International Law of Expropriation. American Journal of International Law, 85, 474-505. https://doi.org/10.2307/2203108

Schmitt, M. N. (2011). Military Necessity and Humanity in International Humanitarian Law: Preserving the Delicate Balance. In Essays on Law and War at the Fault Lines (pp. 89-129). The Hague: TMC Asser Press. https://doi.org/10.1007/978-90-6704-740-1_3

Singh, N. N. (1970). The Absence of a Sovereign Legislature and Its Consequences for International Law. Malaya Law Review, 12, 277-297.

Weil, P. (1983). Towards Relative Normativity in International Law? American Journal of International Law, 77, 413-442. https://doi.org/10.2307/2201073 